\title{
Controversies in the management of stage IIla non-small-cell lung cancer
}

The eighth edition of the tumor-node-metastasis (TNM) classification classified stage III non-small cell lung cancer in substages IIIA, IIIB, and IIIC.

There is no further subclassification but Stage IIIA represents already a heterogeneous group of lung cancers invading chest wall/mediastinal organs or with concomitant N2 disease. Even the involvement of N2 stations includes different subcategories (single-, multi-level, bulky disease).

This heterogeneity poses a tremendous challenge for surgeons, oncologists, radiation-oncologist involved in the management of patients with Stage IIIA disease.

We would like to provide with this series a comprehensive overview about management of stage IIIA lung cancer by leading experts internationally recognized.

Under the assumption that multidisciplinarity should be the key stone in decision making process, we consider this series like a journey between several controversies that so far have not yet been resolved.

\section{Acknowledgments}

Funding: None.

\section{Footnote}

Provenance and Peer Review: This article was commissioned by the editorial office, Current Challenges in Thoracic Surgery for the series "Controversies in the Management of Stage IIIA Non-Small-Cell Lung Cancer". The article did not undergo external peer review.

Conflicts of Interest: Both authors have completed the ICMJE uniform disclosure form (available at https://ccts.amegroups. com/article/view/10.21037/ccts-21-21/coif). The series "Controversies in the Management of Stage IIIA Non-Small-Cell Lung Cancer" was commissioned by the editorial office without any funding or sponsorship. FM and MS served as the unpaid Guest Editors of the series. The authors have no other conflicts of interest to declare.

Ethical Statement: The authors are accountable for all aspects of the work in ensuring that questions related to the accuracy or integrity of any part of the work are appropriately investigated and resolved.

Open Access Statement: This is an Open Access article distributed in accordance with the Creative Commons AttributionNonCommercial-NoDerivs 4.0 International License (CC BY-NC-ND 4.0), which permits the non-commercial replication and distribution of the article with the strict proviso that no changes or edits are made and the original work is properly cited (including links to both the formal publication through the relevant DOI and the license). See: https://creativecommons.org/ licenses/by-nc-nd/4.0/. 


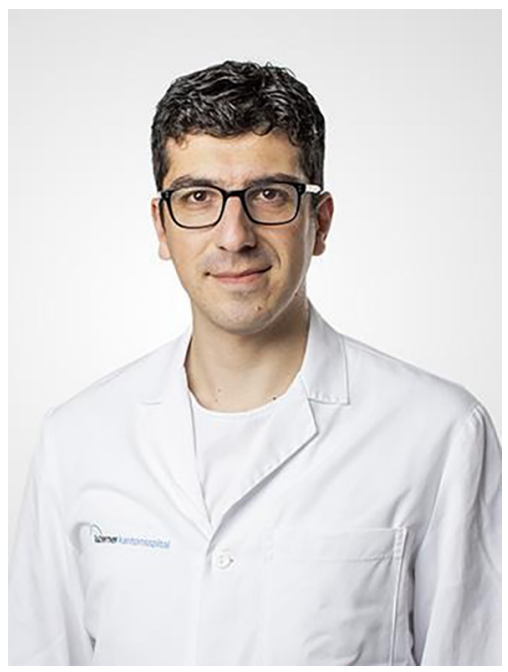

Fabrizio Minervini

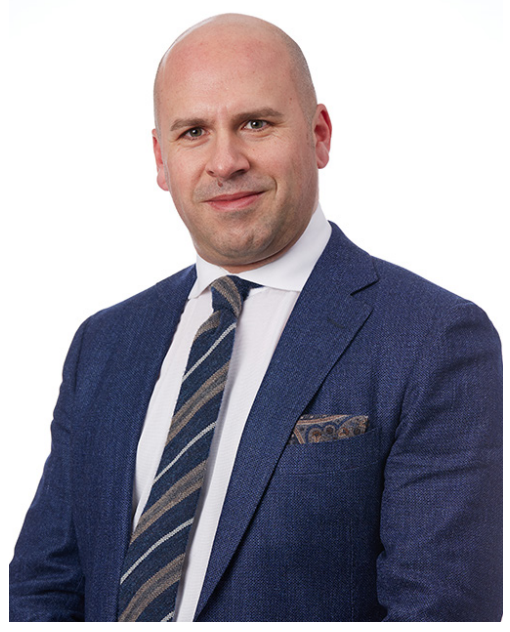

Marco Scarci

Fabrizio Minervini, $\mathbf{M D}, \mathbf{P h D}$

Department of Thoracic Surgery, Cantonal Hospital Lucerne, Lucerne, Switzerland. (fabriziominervini@botmail.com)

Marco Scarci, MD

Department of Thoracic Surgery, San Gerardo Hospital, Monza, Italy. (marco.scarci@mac.com)

Received: 19 April 2021; Accepted: 29 April 2021; Published: 25 August 2021. doi: $10.21037 /$ ccts-21-21

View this article at: http://dx.doi.org/10.21037/ccts-21-21

doi: $10.21037 /$ ccts-21-21

Cite this article as: Minervini F, Scarci M. Controversies in the management of stage IIIa non-small-cell lung cancer. Curr Chall Thorac Surg 2021;3:22. 